\title{
Technology, Innovation and National Manufacturing Competitiveness
}

\author{
Victor, Okongo Ebin ${ }^{1} \quad$ Kayang, Kelvin Kayang ${ }^{2 *}$ \\ 1.Voegs integrated resources Limited, A41 Adisa Estate, Gudu, Abuja- Nigeria \\ 2.Demichelis Investment Limited, 29 Jedo Estate, Airport Road, Abuja- Nigeria
}

\begin{abstract}
Technology and innovation are key factors in achieving manufacturing competitiveness, and have nullified the forces shaping competition. The paper explores the literature on technology, innovation and competitiveness, and discusses the relationship amongst the variables with a focus to understand the role of technology and innovation in fostering national manufacturing competitiveness. The study adopts an exploratory approach and involves the synthesis of extant literature.
\end{abstract}

Keywords: Technology, innovation, competitiveness, manufacturing competitiveness, globalization

DOI: $10.7176 / \mathrm{EJBM} / 11-4-01$

\section{Introduction}

Globalization has accentuated the awareness and importance of international competition in which countries are adopting more dynamic approaches to deepening competitiveness in the quest to increase their share of global trade. Globalization has changed the economic fabric of the world and manufacturing supply chains in profoundly significant ways (Hanley, 2013), which has presented a risk and opportunity profile that is difficult to adapt to (OAS, 2005). Hanley (2013) argued that over the last twenty years, rapid globalization has occurred and the global manufacturing eco-system has undergone immense changes, impacting the prosperity of more economies, firms and people at any time since the industrial revolution. As such this implies, achieving manufacturing competitiveness is key to national prosperity.

In the new global economy, manufacturing competitiveness thrives on innovation and technological change (OAS, 2005). This is as a result of the fact that rapid technological progression is increasingly integrating the world and thus transforming the previously dispersed world economy into a single market (Akis, 2015). As such Countries can raise their gross domestic product base through technical advances which is contingent on cumulative activities of developers, producers and users of technology through their interaction (Borrus \& Stowsky, 1997). Deloitte (2016) reported that countries like the United States, China, Japan, and the United Kingdom, which occupies the top position in the global manufacturing competitiveness index (GMCI), achieved manufacturing Competitiveness through a high Innovation propensity, a strong industrial ecosystem and investment in advanced manufacturing technologies.

This study attempts to examine the role of technology and innovation in enhancing national manufacturing competitiveness while establishing the relationship between the variables.

This paper is structured as follows: Section two focuses on the literature review, and the overview of Technology, innovation and Competitiveness. The relationship between technology and Innovation, technology and manufacturing competitiveness, and innovation manufacturing competitiveness is discussed in section three. The last section provides a conclusion to the paper.

\section{Literature Review}

The classical models of economic growth demonstrate how technological change is exogenous and as such is beyond the purview of economic policies. However, from the 1970s and onwards, endogenous frameworks have illustrated how technological change can be efficiently initiated through science inclined policies. This was hypothesized through approaches such as raising budgets on general education, information and communication technologies, research and development among others. These were emphasized because science, technology and innovation variables have been established as essential ingredients for long term economic growth (Ercan \& Sefer, 2011). The pace of manufacturing development becomes truncated in economies where too few resources are invested in education, scientific research and efforts towards raising the stock of human capital for new idea generation (Borrus \& Stowsky, 1997). This view accentuates the importance of technological capacity building for current and future national manufacturing competitiveness. This is especially so as, once an economy undertakes technical education and training, the rewards compound overtime (Borrus \& Stowsky, 1997). Through a range of interactions between countries, globalization provides for elevation of socioeconomic status in the developing world through adoption of manufacturing technologies, innovation and trade (Todaro \& Smith, 2011).

However, there are differences in the way manufacturing drives economic growth between low income and high income. In developing economies, manufacturing investments focus more on capital expenditure, energy 
requirements and natural resource conversion, while in developed economies manufacturing competitiveness derives from productivity (UNIDO, 2016). Thus for third world countries, increasing manufacturing effectiveness depends to a certain degree among others on investment in modern economic structure in the form of transportation, water system, telecommunication, housing and other supporting infrastructure. These will enhance the manufacturing value added (MVA) process especially when coupled with new productive technologies deployed in primary production (Agola, 2016). This technology effectiveness was at the core of Japan's transition and catch-up in manufacturing competitiveness through a robust technology management strategy that leveraged on massive adoption of foreign technology (Agola, 2016). The lack of a critical stock of technology in manufacturing effectiveness is typified in Africa, the continent with the lowest level of technology deployment in manufacturing activities (Agola, 2016). Despite the underscored benefits of globalization in strengthening manufacturing effectiveness, there are latent demerits for globalization for developing economies. Demerits become evident when these economies become locked into patterns of dependence which can play out in the form dualism or the exclusion of particular segment of an economy from the gains from manufacturing growth (Todaro\& Smith, 2011). Furthermore, globalization can additionally affect developing economies negatively as the accelerated integration of the world economy is turning political blocks into trade blocks in which products and financial markets are collapsing national boundaries (Akis, 2015). This can work for or against countries manufacturing growth strategies depending on particular circumstances.

\subsection{Technology}

The term "technology" has no universally accepted meaning or interpretation as it has been viewed differently by various researchers depending on their School of thought, organizations, objectives and research background (Willoughby, 1990; Sazali et al., 2012). According to Grubler (1998), technology consists of objects manufactured for the purpose of enhancing human capabilities which enable humans to perform task they could not perform otherwise. A limitation of this view of technology is that it does not take in to cognizance the role of "knowledge". From another perspective, technology refers to a level and form of knowledge application (Obradovic et al., 2015) by individuals, organisations and the economy as a whole in supporting value creation (White and Bruton, 2007). Namedo et al. (2016) describe technology as a device for wealth formation through the integrated functioning of people, processes and products. Technology is a tool of net job creation through the generation of more jobs than are eliminated, achieved through the mechanism of new inputs, new processes, new products, and new service delivery which culminate in economic growth and diversification (Borrus and Stowsky, 1997).

Van Wyk (2004) define technology as competence created by people and expressed in devices, procedures and human skills. Momaya and Ajitabh (2005) provided a more robust definition of technology, which they consider "as all the knowledge, product, processes, tools, methods and systems employed in the creation of goods or in providing services". While scholars like Willoughby (1990) define technology as the ensemble of artefacts intended to function as relatively efficient means. He argues that " artefacts incorporates knowledge, but emphasized that such knowledge need to be realized, incarnated, embodied and objectified if it is to be deemed technology. There are different classifications of technology, Mansfield (1975) classified technology in to two forms: the first, disembodied technology, refers to knowledge and expertise expressed in written or electronic form in which value can only be appropriated through intellectual property protection and upon transferability. While the second, embodied technology, refers to knowledge embedded in product or process, and whose value can be appropriated by subsequent sale and profit. Khalil (2000) classified technology in to:

i. new technology - this refers to a technology newly introduced and implemented which might not necessarily be new to the world, but new to the organisation or nation. This type of technology improves organisational and national productivity and competitiveness by impacting the process of product creation and service provision. An example is the implementation of new methods of payment.

ii. emerging technology - these are technologies that have been produced, but not fully implemented. They have the potential to render existing technology obsolete, and can facilitate organisational and societal transformation. An example is artificial intelligence.

iii. high technology - these are more advanced and highly sophisticated technologies that characterises organisations with highly skilled workforce, significant level of research and development (R\&D) expenditure/investment, shortened technological innovation time. It also confers on potential competitive advantage to organisations or nations. For example, telecommunications equipment manufacturers.

iv. low technology - this are widely utilized technologies across different industries. They characterise organisations with low skilled workforce, low level of research and development (R\&D) expenditures and manual and semi automatic operation. An example is a technology for clothing production. 
v. medium technology - this type of technology lies between high and low technology.

vi. appropriate technology - refers to technologies which could either be low, medium or high in which there is a fit between the technology utilization and absorptive capacity. Appropriate technology utilization is important because it facilitates resource and labour efficiency resulting in high productivity.

vii. codified and tacit technology - codified technology are technology that are expressible, and are easily transferable. It focuses more on the "know-how" but not "know-why". Tacit technology on the other hand, refers to non-articulated knowledge whose transferability can only be achieved through apprenticeship, close contact and interaction with an expert

\subsection{Innovation}

Innovation in recent times has garnered increased attention amongst organizations and nations. It has become a necessity owing to the rapidly changing competitive landscape where comparative advantage alone is no longer the basis for competition. The organization of Economic Cooperation and Development (OECD) define innovation as the implementation of new or significantly improved products, service, or process, a new marketing method, or a new organization method in business practices, workplace organizations, or external relations. Borrus and Stowsky (1997) refer to innovation as the basis for new idea generation which is the source of technological advancement. They add that innovation or the adoption of technologies implies investment appropriated in quality improvement of existing technologies. Innovation is a new approach that culminates in small or large improvements that are recognizable, new or different (Smith, 2009). This definition corroborates the view of Elg (2014) which posits Innovation as the process by which new product, processes, methods and services are created. Sida (2015) define innovation as the use of knowledge, ideas, technologies and processesin to product, procedures, and services that bring added value and are new in a specific context. Innovation occurs in networks and involves significant as well as complex interactions among actors such as universities, research institutions, government agencies, industries, and the civil society.

Innovation is usually stimulated by the mobilization of resources in networks, capacity to produce and use new knowledge, pooling financial investments to and establishment of strategies and regulations (Sida, 2015). Tidd (2006) gave the following reasons below for innovation, (i) shock triggering innovation, (ii) the proliferation of ideas, (iii) the essential role played by top management in criticizing innovation, (iv), the frequent restructuring of innovation through various interacting mechanisms, (v) the role of the political process for successful innovation, (vi) the arising outcomes that occur from developments in innovation and (vii) setbacks arising from in effective innovation management.

Stanton et al. (1994) as cited by Egbetokun et al. (2010) provided seven phases of the innovation process:

i. idea generation - this is the stage where ideas are generated. This can done through brainstorming, attribute listing, and /or need identification.

ii. screening of ideas - ideas generated are evaluated and weighed based on the risk, benefits, and potential for success.

iii. research \& development ( $R$ \& D) - the sustainability of the idea is tested at a particular time and in a particular place at this phase. It does not test the objective merit of an idea.

iv. business analysis - analysis is carried out to see if the idea will be profitable- product profitability and market demand are estimated.

$\mathrm{v}$. prototype development - ideas on paper are translated in to product.

vi. testing marketing - product are developed for a niche markets to test it acceptability and performance.

vii. commercialization - This is the final stage where product (innovation) is fully launched in to the market, and operations are scaled up.

Most successful innovations do not happen by chance and are product of unusual effort -purposeful search for innovation (porter, 1990; Drucker, 2002). Drucker (2002) highlighted seven sources of innovative opportunity, namely: (i) unexpected occurrences (success or failure) - innovation arising from unexpected success or failure ; (ii) incongruities - discrepancy between what is and what "ought" to be or between what is and what everybody assumes it to me; (iii) process need - seeking to perfect an already existing process. It entails looking for a "missing link" in an existing process and improving on; (iv) industry and market changes refers to innovative opportunity created as a result of changes in customer preference, taste, and new values, as well as communication and computing technology; (v) demographic changes - changes in population, age, income, education also present a huge source of innovative opportunity; (vi) changes in perception and meaning - this refers to changes such as socio-cultural that alters peoples' perception hence their interpretation and meaning of event or situation; and (vii) New Knowledge - this source of innovative opportunity often leads to radical or disruptive innovation. It has the highest lead time compared to other sources of innovative opportunity. That is, from patenting down to commercialization. It is based on the combination of different inputs of knowledge. $\mathrm{R} \& \mathrm{D}$ is an example of this source of innovative opportunity. 


\subsection{National Competitiveness}

The term "competitiveness" or "competitive power" is incompletely understood by the conventional usage of the term. For instance, it has been wrongly equated with productivity, whereas productivity refers to economic output per unit of input (Atkinson, 2013). In simple terms, productivity is the measure of efficiency (Siudek and Zawojska, 2014). However, competitiveness can be viewed both at the microeconomic level (firm) and macroeconomic level (national). For the purpose of this study, attention will be directed at national manufacturing competitiveness. What then is national competitiveness and manufacturing competitiveness? From the macroeconomic standpoint, several scholars have provided different interpretation of the competitiveness concept. Haque (1995) define national competitiveness as the ability of a country to produce goods and services that meet the test of the international markets and simultaneously to maintain and expand the real income and also rise in welfare level of its citizen. World Economic Forum (1996) refers to national competitiveness as the ability of a country to achieve a sustainable high growth rate in gross domestic product (GDP) per capita.

Competitiveness is defined as the capability of an economy to maintain increasing standards of living for those who participate in it, by attracting and maintaining firms with stable or rising market shares in an activity (European Competitiveness Index, 2006) as cited by Snieska and Venckuviene (2009). For Atkinson (2013), competitiveness is viewed in terms of countries effectiveness in coordinating all of its competences and resources including its manufacturing capacity so as to raise the living standards of its citizens. Central to all these views on national competitiveness, is the place of welfare.

2.3.1 Manufacturing Competitiveness

Prasad (1996) define Manufacturing competitiveness "world-class manufacturing” to mean surface growth and earnings through building customer loyalty-by creating high value products in very dynamic global markets. He posit that manufacturing competitiveness is attained when "the goodness of product and services far outweighs the process and methodologies expended to produce it". This then mean that firms and nations striving to achieve manufacturing competiveness must develop or adopt a system of producing large number of high quality goods and services at lower cost (competitive price).

Porter (1990) argue that manufacturing competitiveness is not absolute, and thus nations adopt industry specific manufacturing competitiveness.

\subsubsection{Measurement of competitiveness}

Neslihan and Huseyin (2012) outlined three indices for measuring competitiveness; the first is the World Economic Forum Global Competitiveness Report (WEF-GCR), which provides an assessment of countries ability/capacity to cater for the wellbeing of its citizens using twelve pillars/indicators. While the second, the World Competitiveness Yearbook- prepared by Institute for Management Development (IMD), assesses countries performance using 340 competitiveness indicators. The last, the ease of Doing Business Reportprepared by International Finance Corporation, ranks countries based on conducibility of business environment.

\section{Technology, Innovation and National Manufacturing Competitiveness: The Nexus}

\subsection{Technology and Innovation}

Technology and innovation are associated concepts that represent different concerns (White \& Bruton, 2007). The interplay of technology and innovation can also be looked from technological innovation as a chain between the stock of technical knowledge and further additions to this knowledge which becomes reinforced in macro level manufacturing (Todaro\& Smith, 2011). As such in today's dynamic and complex socioeconomic world, technology plays a significant role in the innovation function (Sahlman, 2010). In the technology-innovation spectrum, the former is the forerunner which high income economies have leveraged over the years in maintaining their manufacturing competitiveness. Innovation, the latter has been harnessed through ingenuity in production, branding, packaging, inventory systems, marketing, distribution, transaction processing as constituents of industrial competitiveness over developing economies (Todaro \& Smith, 2011). The technologyinnovation continuum is further particularly visible and important in manufacturing through the diffusion process that extends from creation of new tools, equipment and machines (OECD, 1997). The technology-innovation nexus manifests in the importation of manufacturing technology which typically yields higher returns to originating economies than the importing developing countries (Ranis, 2011).

The technology-innovation link in manufacturing can further be stated in the case of less developed economies to make returns on technology purchase through innovative strategies such as reverse engineering and recalibration. This approach can be customized to suit each developing countries unique economic need as a device of enhancing manufacturing competitiveness, which may be a more effective approach than developing science, technology and innovation cycle from scratch (Ranis, 2011). Technology and innovation are as well unified through the strategy function of management. Where strategy is crucial for creation of value, long term success and competitive survival of economies with their constituent productive units (Sahlman, 2010). In a similar vein, technology and innovation are integrated through the marketing function, in which the former pertains to knowledge creation and the latter to knowledge transfer (Sahlman, 2010). Beyond the manufacturing 
sector, firms and public institutions as components of national economies are constantly adapting to developments in technology as well as the resulting innovations which culminate in improved value chain systems that evolve manufacturing and the entire economies (Sahlman, 2010). The technology and innovation bond is visible through the influence by and on economic policy towards national manufacturing growth (Ercan \& Sefer, 2011). As a consequence, technological change and innovation investments are continuously striving for optimal returns in manufacturing competitiveness (Sahlman, 2010).

\subsection{Technology and national Manufacturing Competitiveness}

Technology is an important source and enabler of Competitiveness (Momaya and Ajitabh, 2005). It is seen as a means to achieving competitive advantage, identifying and locating a viable niche. Technology is indeed the "game changer" that has reconfigured the rules of competition in most industries. Knowledge in the form of technology is an important input in the manufacturing production function (Krugman \& Obstfeld, 2009). This is because technological progress and national manufacturing competitiveness have been seen to be strongly associated with local capabilities which must exist in minimum critical mass as an enduring potential for productivity at the frontier (Borrus \& Stowsky, 1997). This view is further strengthened by Porter (1990) finding that competitive advantage is created and sustained through a localized process. In line with the above, technology can be fused with manufacturing competitiveness through human resource endowments which accentuates manufacturing competitiveness evidenced by an increased propensity to harness natural resources, sustain productivity and higher exports (Todaro \& Smith, 2011). In support of the view above, technology fosters manufacturing competitiveness by deepening research and development outcomes that fuel manufacturing growth (Namedo et al., 2016). Nonetheless, the benefits of technologies in manufacturing may not be fully realized by low income economies solely through the technology transfer channel. This is because embedded in these technologies are tacit elements that demand commensurate innovative capacity for further investment, the dexterity to understand, adapt, deploy and improve respective technologies (Todaro \& Smith , 2011). This status quo situates low income economies in an extremely disadvantaged position with industrial economies that have comparatively better manufacturing output (Todaro \& Smith, 2011).

The technology-manufacturing association is also understood through the fact that developed economies have reinforced competitiveness in their industrial sector through higher technological profiles that enable low cost leadership as ingredients for export competitiveness (Todaro \& Smith, 2011). Also of importance in this regard is the concern of appropriability which borders on socially optimum investment in manufacturing through strategies that deter over or under investment in technology (Borrus \& Stowsky, 1997). These validate that nations must device articulated strategies that fuse technology with manufacturing competitiveness through effective policies (Atkinson, 2013). From a different but complementary view, the technology-manufacturing link manifests in country's ability to optimize through gross learning by doing in production as well as learning by using in consumption (Borrus \& Stowsky, 1997). Prasad (1996) highlighted some key technologies that impacted the manufacturing industry, they include the just-in-time system; rapid prototyping; lean manufacturing and pull system. Prasad (1996) note that while technology is a key factor in Competitiveness, technology itself cannot create a long-lasting Competitive advantage. He argued that manufacturing is a vulnerable sector and sustained manufacturing Competitiveness is more easily attainable through continuous innovation. Porter (1990) also note that once Competitiveness is gained through Innovation, it is effectively sustained through relentless improvement. From the above, we submit that innovation is the basis for long-term competitive advantage.

\subsection{Innovation and National Manufacturing Competitiveness}

There are a number of views of the innovation and manufacturing competitiveness nexus, a few are considered here. Innovation entails building new competencies, new capabilities and new knowledge (Egbetokun et al., 2010). It is marked by high uncertainty as differently situated enterprises and economies respond to potential risks and opportunities based on their innovation path and propensity to innovate (Borrus \& Stowsky, 1997). Innovation relates to manufacturing competitiveness as it ensures goods and service become cheaper following the introduction of new technologies, which spurs competition and raises living standards (Cheng et al., 1999). The nexus of these variables is also evident by the fact that innovation in manufacturing is more important than natural resource stock in sustaining economic growth (Obioma, et al., 2015). This infers that in a knowledgedriven global economy diffusion of innovations in manufacturing must be a priority and necessary condition for efforts at manufacturing competitiveness (Ercan \& Sefer, 2011). This is especially so as the generation and exploitation of knowledge have now become major factors and forces of wealth creation. Furthermore, innovation through knowledge diffusion complements manufacturing through its expansion effect on the production possibility frontier (Ercan \& Sefer, 2011). The innovation-manufacturing nexus also stems from the possibilities of larger markets in which volume demand accelerates the integration of production and consumption which among others contributes to revenue growth.

Nevertheless, despite the level of insight on the role of innovation in manufacturing competitiveness, a clear 
understanding of the various channels through which innovation sustains the competitiveness of domestic industries in oversea markets is still lacking (Castellacci, 2006). Likewise, in addition the broad consensus that sectoral innovation and intersectoral knowledge spillovers are necessary for the dynamics of manufacturing and the economic system in general, conclusions on the effectiveness of different spillover mechanisms have not been reached (Castellacci, 2006). This is more so as knowledge flows are easy to discuss in academics, but more challenging to quantity in empirical analysis (Castellacci, 2006). Nonetheless, due to fact that the manufacturing sector is less volatile than other technological industries, innovation is still a viable input for manufacturing competitiveness across countries. The importance and thus relationship between innovation and manufacturing competitiveness is also substantiated by the fact that long run international competitiveness in manufacturing has been found to be robustly dependent on diffusion of advanced knowledge (Castellacci, 2006). Even classical economic growth theory implicitly highlights the innovation-manufacturing linkage by situating innovation arising from technological change at the core of long run growth manufacturing models (Ercan \& Sefer, 2011).

\subsection{Conclusion}

Globalization has diffused the consciousness and prominence of global economic rivalry; as a consequence, economies around the world are becoming more aware of the implications of their socioeconomic undertakings. Economic planners must deepen their scientific logic, and decision making processes, as well as, adopt a proactive approach in developing macroeconomic policies. The implications of technology, innovation and manufacturing effectiveness is parallel with the tenets of historical economic models developed to improve overall national socioeconomic welfare. Technology and innovation are constituents of competitiveness as they have enabled nations outperform traditional factors of production, as well as, intensify and nullify competitors experience effect. Technology, innovation and manufacturing Competitiveness have been shown to function along paths which portend overlapping interactions that can yield value to households, firms and nations. Manufacturing competitiveness, has been shown to be technology and innovation-driven, as well as being prerequisites for nations to achieve and sustain industrialization. As such, effective strategies should be devised to integrate technology and innovation towards attaining competitive advantage.

\section{Acknowledgement}

The Authors acknowledges that this research did not receive any specific grant from funding agencies in the public, commercial, or not-for-profit sectors.

\section{References}

Agola, N. O. (2016). Growth and Development in Africa. Berline Heidelberg: Springer-Verlag. DOI: 10.1007/978-3-662-49557-5_2

Akis, E. (2015). Innovation and Competitive Power. Procedia- Social and Behavioural Science, 195, 1311-1320

Atkinson, R. D. (2013). Competitiveness, Innovation and Productivity: Clearing up the Confusion. The Information Technology and Innovation Foundation.

Borrus, M., \&Stowsky, J. (1997). Technology Policy and Economic Growth. Cambridge: MIT Press.

Castellacci, F. (2006). Innovation and International Competitiveness of Manufacturing and Service Industries: A Survey. DIME Working Paper

Cheng, L. K., Qiu, L. D., and Tan, Q. (1999). Technology Transfer, Foreign Direct Investment and International Trade. Retrieved at https://core.ac.uk/download/pdf/7354563.pdf

Deloitte (2016). Global Manufacturing Competitive Index. Deloitte Touch Tohmatsu Limited.

Department of Trade and Industry. (1998). Our Competitive Future: Building the Knowledge Driven Economy. London, UK: DTI, Economics and Statistics Directorate.

Drucker, P. F. (2002). The Discipline of Innovation. Havard Business Review. August Issue. Retrieved at https://hbr.org/2002/08/the-discipline-of-innovation

Ercan, S. A., \&Sefer, S. (2011). The Effects of Science-Technology-Innovation on Competitiveness and Economic Growth. The 7th International Strategic Management Conference. Elsevier.

Egbetokun, A. A., Siyanbola, W., and Adeniyi, A. (2010). Indigenous Innovation Capability in Sub-Saharan Africa: A Review of the Nigerian Situation. Munich Personal RePEc Archive (MPRA).

Elg, L. (2014). Innovation and New Technology- What is the Role of Research? Implications for Public Policy. Vinnova Analysis, 05.

Fagerberg, J. (1996). Technology and Competitiveness. Oxford Review of Economic Policy, 12(3), 39-51.

Grubler, A. (1998). "Technology: Concept and Definition". Technology and Global Change, 19-89. Cambridge, M.A: Cambridge University Press.

Haque, I. (1995). “Technology and Competitiveness". Technology, Trade and International Competitiveness, World Bank.

Hanley, T. (2013). “Manufacturing Competitiveness". Fourth Bruges European Business Conference- Europe as 


a Location for Industry and $\quad$ Innovation. $\quad$ Retrieved from
http://tim_hanley_presentation_college_of_europe_23april2013.pdf

Khalil, T. (2000). Management of Technology: The Key to Competitiveness and WealthCreation. New York: Irwin McGraw Hill

Krugman, P. R., \&Obstfeld, M. (2009). International Economics: Theory and Policy (8th Edition). Pearson International Edition.

Melitz, M. J., \&Trefler, D. (2012). Gains from Trade when Firms Matter. Journal of Economic Perspectives, 26(2), 91-118.

Manfield, E. (1975). International Technology Transfer: Forms, Resource Requirements and Policies. American Economic Review, 65, 372-376.

Momaya, K., and Ajitabh, A. (2005). Technology Management and Competitiveness. Is there a Relationship? International Journal of Technology Transfer and Commercialization, 4(4), 518-524.

Namedo, P., Ansarie, M. A., and Bhatnager, A. (2016). Introduction to Technology Management. Industrial Engineering and Management, 5(3). DOI:10.4172/2169-0316.1000195

National Competitiveness Council (2015). Ireland Competitiveness Scorecard. NCC: Dublin.

Neslihan, A., and Huseyin, T. (2012). Defining and Measuring Competitiveness: A Comparative Analysis of Turkey with 11 Potential Rivals. International Journal of Basic and Applied Sciences, 12(02), 31-43.

Obioma, B. K., Anyanwu, U.N, and Kalu, A.O. (2015). The Effect of Industrial Development on Economic Growth (An Empirical Evidence in Nigeria 1973 - 2013). European Journal of Business and Social Sciences, 4(2), 127 - 140.

OECD (1997). National Innovation System. Paris: OECD Publisher.

OAS (2015). Science, Technology, Engineering, and Innovation for Development. A Vision for the Americas in the $21^{\text {st }}$ Century. Organization of American States.

Obradovic, D., Ebersold, Z., and Obradovic, D. (2015). The Role of Technology Strategy in Competitiveness Increasing. Economic Annals-XXI, 1-2(1), 32-35.

Obradovic, D., and Obradovic, D. (2015). The Role of Innovation on Strategic Orientation and Competitiveness of Entreprises. Ecoforum, 5[1(3)], 90-95.

Porter, M. (1990). The Competitive Advantage of Nations. Harvard Business Review. March- April Issue.

Prasad, B. (1996). "Maintaining Competitiveness". Concurrent Engineering Fundermenrals, vol 1: Integrated Product and Process Organisation Edition. Upper Saddle River, New Jersey: Prentice Hall PTR

Ranis , G. (2011). Technology and Human Development. Center Discussion Paper, No. 1004, Yale University, Economic Growth Center, New Haven, CT.

Sahlman, K. (2010). Elements of Strategic Technology Management. Faculty of Engineering, University of Oulu (Ph.D Dissertation).

Sazali, A. W., Raduan, C. R., and Suzana, I. W. (2012). Defining the Concept of Technology and Technology Transfer: A Literature Analysis. International Business Research, 5(1), 61-71

Siudek, T., and Zawosjka, A. (2014). Competitiveness in the Economic Concept, Theories and Empirical Research. Oeconomia, 13(1), 9-108.

Sida (2015). Support to Innovation and Innovation System. Innovation Working Group, Unit for Research Cooperation at Department of Partnership and Innovation. Retrieved at https://www.sida.se/globalassets/sida/eng/publications/position_paper_support_to_innovation.pdf

Smith, T. (2009). Innovation in Public Education: Prospect and Opportunities. New School Venture Fund.

Snieska, V., and Venckuviene, V. (2009). Venture Capital Impact on the Region's Competitiveness. Economics and Management. Retrieved at https://researchgate.net/publication/251761945

Stanton, W. J., Etzel, M. J., and Walker, B. J. (1994). Fundermentals of Marketing (10 ${ }^{\text {th }}$ edition). New York. Mc Gray Hill, Inc.

Tidd, J. (2006). A Review of Innovation Models. Imperial College, London/ Tanaka Business School. Discussion Paper 1.

Todaro, M. P., and Smith, S. C. (2011). Economic Development (1 $1^{\text {th }}$ ed.). Boston, M.A: Addison-Wesley.

UNIDO. (2016). The Role of technology and Innovation in Inclusive and Sustainable Industrial Development.

Van Wyk, R. (2004). Technology: A Unifying Code. A Simple and Coherent View of Technology. Cape Town: Stage Media Group

WEF (1996). The Global Competitiveness Report. Geneva: Switzerland.

White, M. A., and Bruton, G. D. (2007). The Management of Technology and Innovation: A Strategic Approach. Canada: Thompson South-West .

Willoughby, K. W. (1990). Technology Choice: A Critique of Appropriate Technology Movement. Bouldon and London: West View Press. 


\section{Biographical Notes}

$>$ Victor, Okongo Ebin is a management consultant with over a decade experience in energy, strategy, economic and psychometric modeling, business competitive planning and operations management. His research interest includes; international economics, development economics, technology management, and innovation management. He received his Bachelor of Science degree in Economics from the University of Jos, and a Post Graduate Diploma in Technology Management from the National Centre for Technology Management, Ife in 2002 and 2014 respectively. He also received his master degree in Technology Management from the Federal University of Technology, Minna in 2018, all in Nigeria.

Kayang, Kelvin Kayang received his master degree in Technology Management from the Federal University of Technology, Minna in 2018. He is a freelance consultant with experience and trainings in project management, public-private partnership, management, businesses modeling, and innovation management. 